\title{
Social Intimacy
}

\section{Andrew Dawson and Simone Dennis}

\begin{abstract}
Авstract: In this article, we highlight how COVID-19 has transformed, is transforming and may transform into the future human intimacies at several different social levels: between couples, within and between families, between citizens and states, among nations, and between people and their deities. We conclude by highlighting an uncertain future for intimacies that may entail the radical transformation of societies characterised by conversely new and liberating forms of socio-economic organisation or enslavement, especially to new spatio-temporal configurations engendered by the pandemic.
\end{abstract}

KeYwords: citizens, COVID-19, intimacy, nations, pandemic, religion, states

In this, the second of the special issues of Anthropology in Action on 'COVID-19 and the Transformation of Intimacy', we move beyond the microbial and the narrowly corporeal to look at social intimacy broadly. This is conceived at multiple scales, from the intimate relationships between couples through to peoples' intimate relationships with their deities.

\section{Intimacy - Transformed and Transformative}

As a field of enquiry in the social sciences, especially in anthropology and sociology, intimacy has a considerable pedigree. As is the wont with such welltrodden fields, the concept of intimacy is slippery with multiple definitions (Jamieson 2011; Register and Henley 1992). Indeed, as Ara Wilson points out, 'its lack of fixity is part of its appeal' (2012: 32).

However, what we can say with certainty is that intimacy is fundamentally relational. As Lauren Berlant puts it, intimacy is 'an aspiration for a narrative about something shared, a story about oneself and others' (1998: 281). And we can say that that sharing has a particular quality. To be intimate is to be able, as Berlant continues, 'to communicate with the sparest of signs and gestures' (1998: 281), as in to intimate.
Beyond this, there is more that can be said about a now commonplace understanding of and set of approaches to intimacy. First, and despite globalisation diffusing ways of being intimate, such as romanticlove marriage (see, for example, Hirsch and Wardlow 2006), largely from the Global North to the Global South, meanings of intimacy and intimate practices vary and are always culturally contingent.

Second, there is increasing recognition of how, and this is perhaps precisely because of their seeming impenetrability, spheres of intimacy are subject to regulation (Pain 2015), especially by states. As several anthropologists have demonstrated, this is especially so in contexts of colonisation (Legg 2010; Povinelli 2006; Stoler 1989, 2006).

Third, it is recognised increasingly that intimate relations extend beyond human to non-human worlds to encompass a range of beings such as, for example, and as we explored in Volume 27, Issue 2, humans' intimate relations with microbes like the coronavirus. Indeed, as lockdown trends such as sourdough baking and the adoption of 'iso-dogs' indicate the pandemic has provided fertile grounds for the flourishing of such intimacies.

Fourth, and relatedly, intimacy can characterise a broad range of relations beyond those that we might normally think of it as pertaining exclusively to: on- 
going interpersonal relations. At a micro-level, for example, scholars of tourism have long observed that one of the appeals of tourism is the opportunity for experiencing intimacy with 'others' (see, for example, Conran 2011) and that, indeed, it is sometimes the very fleetingness of those encounters that engenders that very intimacy. But, it is at macro-levels where, undoubtedly, social science has taken its biggest steps in understanding intimacy in recent years. The seminal work of three scholars in particular stands out: sociologist Anthony Giddens, literary theorist Lauren Berlant, and anthropologist Michael Herzfeld. There is a thread that connects their work.

Giddens argues, amongst other things (see below), that late modernity has entailed sex - that once most private of intimate behaviours - having an increased presence within public life. In turn, sex became a subject of public fascination and, in turn again, the public fascination with sex became in and of itself a focus of academic fascination (see, for example, Soysal 2010). The important point to note is the decoupling of intimacy from privacy. Berlant (2008) draws upon this to develop the idea of the intimate public', which she defines as 'an affective scene of identification among strangers that promises a certain experience of belonging' (2008: viii). She characterises the idea of an intimate public as conveying the collective dimensions of intimacy (2011), which are enabled especially by the consumption of common things and texts (2008). Of course, and as Benedict Anderson (1991) highlighted a long time ago, the key modern form of collectivity enabled by such forms of consumption (largely print capitalism in his analysis) is the nation. In this respect, Herzfeld's concept of cultural intimacy is especially productive and telling. Contra relational theories which define the identity of the nation (and/or ethnic group) as an outcome of its juxtaposition with other such groups (see, for example, Barth 1969), Herzfeld demonstrates how, in what amounts to a sort of dirty laundry theory of the nation, what matters is 'those aspects of an officially shared identity that are considered a source of external embarrassment but that nevertheless provide insiders with their assurance of common sociality' (2005: 7). Herein is a notion of the nation (and, indeed potentially other large communities) as a collective of intimates, where recognition of co-belonging is often communicated by way of furtive intimating.

All of the aforementioned facets of intimacy are reflected upon in articles in this special issue. And, certainly, the works of Giddens, Berlant and Herzfeld provide the intellectual groundwork for the multiscaler approach to intimacy that we adopt (see Vol- ume 27, Issue 2). However, there is one further facet of intimacy highlighted by recent scholarship that is most central to the concerns of this special issue - intimacy transforms.

In The Transformation of Intimacy, Giddens (1992) argues further that late modernity is characterised increasingly by relationships based on trust rather than obligation. His book has been subject to considerable criticism. Notably, at one level, some take issue with his optimism. Where Giddens sees 'pure relationships', Eva Illouz (2007) sees relationships that are increasingly 'cold' and that 'hurt', and Zygmunt Bauman (2003) sees relationships that are increasingly frail, which leads to the dilemma of simultaneously being both desperate to become and wary of becoming intimate. At another level, Giddens is criticised for exaggerating change over continuity in the forms that intimate relationships take (see, for example, Jamieson and Simpson 2013). Nevertheless, and however unevenly, Giddens brings useful attention to the capacity of intimate relationships to transform, and often radically so.

Berlant takes the insight one step further. Intimacy is, she points out, often associated with uncertainty. As she states: "II didn't think it would turn out this way" is the secret epitaph of intimacy" (1998: 281), meaning that, as Kelly Colas extrapolates in Volume 23 , Issue 2 , 'fundamental to intimacy is the tension between the shared assumption of how relationships exist within a particular institution or framework and the reality that unpredicted events can disrupt these expectations at any moment'. But, Berlant continues, in its own right intimacy has the capacity to loop back too and transform the very events that it is transformed by. As she states, intimacy 'creates spaces and usurps places meant for other kinds of relation' (1998: 282). In Berlant's most incisive of words, 'intimacy builds worlds' (1998: 282). In different ways, and to differing degrees, each of the articles in this special issue reflect on how the COVID-19 pandemic transforms intimacies, but also on how the new forms of intimacy produced by the pandemic are, in and of themselves, transforming society more broadly.

\section{Lovers}

The opening two articles, in the section subtitled 'Lovers, Couples and Families', by Lara McKenzie and Van Minh Nguyen, consider how companionship is transformed (or reinforced) by conditions of lockdown. McKenzie illuminates a kind of hege- 
monic coupledom in Australian social policy that percolated through superannuation and tax laws and right into regulatory approaches to physical proximity during the pandemic. With exceptions for people living in households of more than two persons, at various stages a two-person limit was placed on indoor and outdoor gatherings, thereby rendering non-monogamous sexual contact effectively off limits. And, in contrast to many other contexts, such as the Netherlands, where single men and women were actively advised by the state to organise a seksbuddy (Boffey 2020) for lockdown, the sexual needs of single people in Australia were largely ignored, and discussions regarding regulation of touch and physical contact were strangely sexless.

If lockdown in Australia served, as McKenzie puts it, to 'shut down' sex for single people, for many people in Ho Chi Minh City, Vietnam, social distancing acted, according to Van Minh Nguyen, as 'an accelerator of intimacies'. Nguyen's focus is on people on the 'razor's edge of coupledom'. Social distancing disrupted conventional courtship practices. With the requirement to stand six feet apart, auditory practices such as whispering were no longer effective. Likewise, masking-up rendered the subtle visual conventions of courtship, such as forms of visual mimicry, obsolete. And, the normal context for early stage courtship, amongst friends in public places, was now not possible given restrictions placed upon the size of social gatherings. In reaction, Nguyen observes, breaking the norm of the house being reserved largely for family and self only, couples on the cusp of getting together increasingly began to practise early courtship at home. Consequently, in many cases sexual contact and intimacy more generally were fast-tracked. And, Nguyen hints, this challenge to normative patterns of intimacy and sexuality wrought by the COVID-19 pandemic may endure.

\section{Families}

The next three articles continue the consideration of the impacts of social distancing and lockdown particularly, this time on families. Hannah McNeilly and Koreen M. Reece's article, based on fieldwork in Scotland, describes a situation of 'inescapable proximity' and 'forced intimacies' within locked down households. Their work resonates (and might be read in conjunction with) a number of articles in Volume 28, Issue 1 on domestic workers. However, while those articles focus largely on the intensification of the burdens of domestic work during lockdown on women,
McNeilly and Reece consider more women's creative responses. Their informants are multi-taskers, who balance roles as professionals, domestic workers and parents. Crucially, they describe how, in the inescapable proximity of lockdown, the spatial and temporal boundaries between these roles collapse in apparently unsustainable ways, disrupting even these women's senses of selfhood. However, they go on to describe how this is followed invariably by experimentation with adaptable new domestic arrangements and, regarding matters of selfhood, 'continuous reflexive evaluation and readjustment' (see also McGahey in Volume 28, Issue 1).

In contrast to the condition of being locked-in together, Bob Simpson's article considers the ICTenabled communications between three generations of his own family, which was forced to be spatially separated by lockdown across different parts of the United Kingdom. While the haptic metaphor of 'keeping in touch' via the use of such technologies might appear to be curiously inapt, he finds that, in many ways (and via the kinds reflexive adjustments and performative adaptions discussed by McNeilly and Reece) the social relations experienced by family can be 'intensified' and that 'slower, more caring and more intimate ways of being together' eventuate.

Sarah Pink and colleagues reach similar conclusions, albeit focussing on the use of ICTs during lockdown by social workers charged with overseeing the welfare of children within families in the United Kingdom. In very specific ways, they chart how ICTs facilitate specific forms of intimacy and knowledge not otherwise available. For example, they describe how mobile phones are used to give social workers valuable insights into the material domestic conditions inhabited by children. Crucially also, they observe how children seem often to be more at ease talking to screens rather than to social workers in-person.

\section{Citizens and States}

Pink and colleagues' article takes us into a consideration of COVID-19 and the transformation of intimate relations between 'citizens and states'. The first two articles in this section, by Senem Kaptan and Jialing Luo, focus on how citizen-state relations were maintained in the pandemic. Kaptan's article considers governmental techniques for maintaining intimate bonds and the contract of obligations between the state and its citizens during the pandemic in Turkey. In such times, those bonds might have been strained 
by additional scrutiny of the performance of government and the social-distancing-induced locking out of the state from everyday lives. Kaptan highlights two techniques that were used for overcoming this situation. The first of these was the president (Recep Tayyip Erdoğan) bestowing a portion of his salary to the nation. This was represented as an act of selfless generosity that demanded, however, reciprocation in the form of the citizenry fulfilling its collective obligations, especially as demanded in measures designed to combat COVID-19. The second was a series of letters written by the president to the people of Turkey and delivered directly to their homes. The style of the letters was patriotic and motivational, reminding citizens of their national duties in pandemic times. Reflecting the qualities of a thank-you gift, the letters were, Kaptan argues, a kind of tribute to the success of the Turkish nation in addressing the impacts of COVID-19. More importantly for the purposes of this special issue, Kaptan observes that the letters brought, affectively speaking and in more intimate ways than other media might have afforded, the presence of the president and the state into people's homes.

While in Turkey state-citizen relations were maintained by one-off gifts and letters, Luo demonstrates how in China this is managed on an ongoing basis by shequ, local communities at whose heart are the Residents' Committees. In normal times, they act as intermediaries between the state and the citizenry, often intervening directly in neighbourhood disputes. During the pandemic, however, they have played a frontline role in combatting the spread of COVID-19, being charged with implementing the lockdown. Speculating on the role of shequ in terms of maintaining citizen-state intimacies going forward, Luo draws subtly different (though not incompatible) conclusions to Junjie Chen in Volume 27, Issue 2. Chen sees shequ serving better and discriminately higher-class members of Chinese communities. For Luo, once the adulation for shequ and the Residents' Committees accrued through their success in controlling COVID-19 recedes, higher-class people with their presumably greater financial resources and state connectedness will come to ignore them.

Then, in what is, it must be remarked, a hugely sophisticated historical and ethnographic institutional analysis, Dave Whyte's article broadens the consideration of citizen-state relations, considering not only how they were maintained, in this case in rural Ireland, but also how intimacies amongst the citizenry itself were deployed in pandemic management, especially pertaining to matters of care. At the heart of Whyte's article is the argument that, rather than a manifestation of neoliberalism, 'the COVID-19 response is better characterised as shaped by the continuation and resurgence of the Catholic nationalist ideology that has been intimately connected to Irish capitalism since the foundation of the state'. Management of the pandemic was organised through what came to be known as the Community Response. This functioned as an umbrella for several organisations, central amongst which is the Gaelic Athletic Association, to which day-to-day governance of the pandemic was dispersed. Crucially, in this context, governance and care were grounded, Whyte explains, 'within a Catholic spatial imaginary'. The parish was the organising spatial unit, and parish-level community voluntarism the form through which governance and care were enacted. What Whyte conveys is a response to the pandemic that hinges on deep institutional and local interpersonal intimacies.

Michael Herzfeld's and Anne Décobert's articles take the discussion of citizen-state intimacies in a new direction, in order to consider the ways in which the pandemic affords opportunities for the ideological agendas of states to be echoed within or challenged by citizenries.

A small summary such as this one cannot do full justice to Herzfeld's brilliantly acerbic meditation on contemporary pandemic Trumpian America. First, reminding us of the critical power of anthropological comparison, he illuminates echoes of the worst aspects this global hegemon in places like Viktor Orbán's Hungary, Rodrigo Duterte's Philippines and Boris Johnson's United Kingdom. However, and more optimistically, he sees the flickerings of better alternatives in places such as Thailand and Greece, two of his main fieldwork sites throughout his career. Second, he offers brilliant flashes of insight into a wide range of issues: political and administrative failure; the contemporary crisis of confidence in expert knowledge; the structural violence of imperial nations; the selfishness of neoliberal thinking; and the contemporary resurgence of 'immature maleness'.

Amongst so many insights, it is hard to pin down Herzfeld's article to only one important contribution. However, it hangs together in its exploration of cultural intimacy, one of several concepts that Herzfeld has contributed to the lexicon of core anthropological ideas. Herzfeld begins by observing that the United States is 'arguably the only country that is truly both imperial and post-colonial at one and the same time. This endows it with both a sense of the power to lead the world ("manifest destiny") and a collective chip on the cultural shoulder'. That chip is a basis for a 
cultural intimacy ... to reiterate the earliest statement of the concept: 'those aspects of an officially shared identity that are considered a source of external embarrassment but that nevertheless provide insiders with their assurance of common sociality' (2005: 7). The particular source of embarrassment that Herzfeld focusses on here is what he calls the 'ugly American', something that often remains hidden in the secrecy of the 'locker room', but occasionally breaks out in 'in-your-face aggression'. Now, the time of Trump and the pandemic is one such time. And, carrying the metaphor of the enclosure of the locker room one step further, Herzfeld argues that lockdown may be a perfect condition for the ugly American to build in captivity before bursting out. The ugly American manifests in a constellation of concerning outlooks, but Herzfeld focusses on an especially salient one. And this is the rendering of American libertarian ideals as selfish freedom to, for example and presciently, deny, as anti-maskers do, elementary hygiene measures and, ultimately, care for the liberty (freedom from death) of one's fellow humans. Finally, Herzfeld argues, this feeds another loop of cultural intimacy, for what the anti-maskers defend is 'a guilty realisation that' they 'are citing freedom to excuse a selfish reluctance to give up convenience and pleasure for the greater good'.

Speaking of COVID-19 and selfishness, Herzfeld states:

There are two pandemics raging around us, each feeding the other, each imitating the other in their attack on the intimacy of everyday sociability. Never was social consciousness more necessary for the survival of common humanity. Never was the idea of a social conscience more comprehensively threatened by a plague of selfishness, hatred and rage.

It would appear at first blush that Décobert might concur. The title of her article on Australia references the 'Toilet Paper Wars', when pandemic-induced panic-buying led to conflict in supermarket aisles. However, she points out, rather than a manifestation of the 'plague of self-interest' the event was, by and large, a result of the media stoking fears of shortages. Furthermore, and outweighing this, Décobert observes an up-swelling during the pandemic of the kind of social consciousness that Herzfeld hopes for. A key example of this is a network of community care groups across Australia called '\#ViralKindness' that connects people in need with others who are willing and able to help. Décobert goes on then to wonder whether phenomena such as this might give grounds for broader initiatives concerned with care and equity. In particular, she wonders whether they may fuel recent calls for a basic income that is granted on the grounds of presence within the nation rather than the more exclusive criterion of national membership. Décobert is cautiously optimistic, and her article convinces us that COVID-19 may be a pivotal moment in this regard. It will, after all, bring profound socio-economic crises that governments must address going forward. And, it brings into sharp relief just how dangerous for all of us neoliberalism can be. For example, as she highlights, precarity, which the right might more euphemistically label as labour force flexibility, has had a direct impact on the spread of the virus. Precarious labourers are reluctant to isolate because that threatens their livelihoods. A basic income would address this. All in all, Décobert's important article conveys how COVID-19 led to a 'surge in solidarity', a political intimacy, if you will, between a new breed of activists themselves and humanity in general.

\section{Nations}

The focus of Marion Hamm's article in the sub-section entitled 'Nations', which is concerned with intra- and international intimacies, is the national celebration of the Day of Liberation in Italy. Her ethnographic focus is the experiences of three women, including herself, from an older style of solidarity movement to that described by Décobert, and how they were affected by the spatial disconnections wrought by lockdown. Hers is a thick description that conveys on one hand the pains of separation, but, on the other, how in many ways their now ICT-mediated celebration of the day together(?) intensified their senses of global intimacy.

Andrew Dawson's article is, like Hamm's, a transnational study of intimate international relations. Based largely on locked-down Zoom transnational communications between himself in Australia and his family in the United Kingdom, it considers how the pandemic might transform senses of national belonging. In particular, and deploying Herzfeld's idea of cultural intimacy, he articulates his own deep sense of embarrassment surrounding how his native British appear to have adjusted catastrophically to the conditions of the pandemic. Conversely, he observes that in Australia, where he is a citizen but not yet quite 'at home' (Rapport and Dawson 1998), the pandemic represented a disemic moment, where the publicly celebrated 'essences' of Australianess, such as free-spiritedness, elided with more embarrassing 
public secrets of Australianess, such as national dispositions to bureaucratise and rule-following. This made for a particularly effective response to the pandemic characterised by healthy defiance of the more dangerous and irrational elements of governmental health advice and a following of rules and procedures where they made good sense. This augured well, he argues, for how Australia came to cope with the pandemic, and for his own now growing sense of Australian (or hybrid Br-Australian) national belonging. Furthermore, he continues, looking into the future this situation may have significant impacts on the shape of Australia's and Britain's intimate postcolonial and post-pandemic international relations more generally.

If England's relations with Australia have, because of colonial legacy, been especially intimate ones, then its relations with Wales have been even more so. Even the border they share is, as Bryonny GoodwinHawkins puts it in her article, a 'non-existence' - a mere administrative line in the hills. A resurgent Welsh nationalism, allowed to flourish partly by devolved government, wishes things could be otherwise. And, it attempts to make an independent Wales come into being largely through symbolic means such as the proliferation of flags and bilingual signs. But, these are nothing compared to a 'hard border'. Crucially, however, Goodwin-Hawkins observes, the pandemic made both the imagining and the reality of a softer border harder and a harder border easier. Central to this was what she labels as Welsh 'epidemiological nationalism'. In essence, the facts and figures of now devolved health authorities were able to represent the danger of the spread of COVID-19 being 'over there' in England. This resulted in various kinds of grassroots and governmental border enactments. For example, border-dwelling residents spray-canned 'GO HOME' on farm fences, and local authorities devised what, as Goodwin-Hawkins puts it wittily, an 'anti-tourism campaign'. Its call was: 'Don't Visit Wales'.

Epidemiology is the theme too of Elżbieta Drążkiewicz's important ethnographic study of scientists charged with producing the statistics through which the COVID-19 pandemic was measured and understood in Ireland. Contextualising her study, Drążkiewicz points out that for various reasons, because Ireland's health care relies more heavily on the private sector than in other parts of Europe, epidemiological statistics have a history of heavy use when it comes to helping people make sense of disease. Furthermore, statistics are, she observes, a key tool of health governance. Notably, 'statistical panic' is a conventional method deployed by health authorities in seeking to engender desired responses amongst the general public. And, during the pandemic statistics were rigidly deployed, dictating the types of interactions (and, thereby intimacies) that the state regarded as essential or permitted and otherwise. The article, then, is an exploration of several different types of intimacy amongst the general public: intimacy with health professionals concerned with the production of statistics; intimacy with the people with whom one was, via diktats issued in light of the statistics, permitted or not to socialise; intimacy with the statisticians (who came temporarily out of their offices and into homes on TV sets); and, above all, intimacy with the statistics themselves.

Initially, Drążkiewicz remarks, the statistics-driven health strategy was very successful. People became exceedingly intimate with the statistics. However, she goes on to remark, this was in many respects counter-productive. The processes of 'commensuration', where qualities (in this case of the lived realities of the disease) are translated into quantities, and of 'reverse commensuration', where quantities are translated into qualities, were, inevitably, inadequate. Consequently, what emerged was, as Drążkiewicz describes it, a 'disconnect' from the disease. In turn, and as the disease spread and people's first-hand experiences with it too, the mediation of statistics became less appealing. Drążkiewicz remarks that 'COVID-19 arrived in Ireland and made everyone fall in love with numbers'. But it seems that, after initially rocking people's worlds, the statistics soon turned out to be a disappointing lover that the Irish public eventually dumped.

\section{Deities and Time}

In the final sub-section entitled 'Deities,' Nadeem Malik's article on urban Pakistan, which is based on fieldwork undertaken during the holy month of Ramadan and during the pandemic, illuminates the importance of ideas of intimacy in Islamic beliefs and practices, both with God and amongst fellow adherents. Furthermore, he argues that pressure for collective and intimate worship from within the Islamic establishment, which was driven as much by economic exigency as by scripture, and was often enacted in defiance of secular health authorities, almost certainly contributed to the virulent spread of coronavirus in that country.

The situation of tension between Pakistan's secular and religious institutions described by Malik is, 
more or less, the converse of that described in the article by Sofya A. Ragozina. Ragozina provides a detailed analysis of the speeches, fatwas and official statements of representatives of the Spiritual Administration of Muslims of Russia, a core body whose aim is to promote 'traditional Islam' over 'radical Islam', and which is clearly loyal to the state. During the pandemic, it served to translate both the political and medical discourses of the state into the language of Islam, and Ragozina offers many striking examples of this effort. The Spiritual Administration of Muslims of Russia enabled, essentially, the 'political regulation of corporeality' during the pandemic amongst Russia's Muslim population.

In the final article, Rebecca Irons discusses time in the pandemic. This may seem at odds with our enquiry into the transformation of intimacy and the matter of deities. However, it is rendered very relevant by its clear resonances with an older form of especially humanist Marxian scholarship that connected capitalism, feelings and temporalities. It pointed out how capitalist industry became 'a specific mode of living and of thinking and feeling life' (Gramsci 1997: 302), and how the modernist clock of the factory was a key factor through which the transformation to capitalism was felt (Thompson 1967). It was, for example the key instrument marking a shift in daily life from other antecedent rhythms, such as those governed by seasonal agriculture and, crucially, those established by the liturgical calendar in the times of gods and religions.

In contrast, Irons' important article identifies what she calls 'Quarantime', a specific mode of timekeeping and reckoning that emerged during the pandemic (see also Dawson Forthcoming) and that, she speculates, may endure. Above all, and largely because of the continual possibility of the presence of those with whom we work and socialise online (and regardless of the time zones they occupy), we have been made aware through lockdown of living in a continual present. Reflecting back not that long ago to the postmodern condition and capitalism described by David Harvey (1989) where, at least, the home was a refuge from the ravages of time-space compression, Irons observes that in Quarantime we face a 'time-prison of temporalities without spaces, and ambient intimacies without cessation'.

The articles in this special issue consider how the COVID-19 pandemic transforms intimacies, but they also consider how the new forms of intimacy produced by the pandemic are in and of themselves transforming society more broadly. Multiple and contextually specific transformations are documented.
On the grandest scale, however, the articles by Irons and Décobert in particular bring into very sharp relief the dramatically different possible potentials that the post-pandemic (we hope) future holds. May, as Décobert sees hints of, COVID-19 bring forms of enduring solidaristic intimacies that portend radical transformation for the better? Or, as Irons seems to indicate, might it produce new kinds of (temporal) intimacies of enslavement?

Andrew Dawson is Professor and Chair of Anthropology at the University of Melbourne. An ethnographer of human mobilities, he has conducted large-scale research projects in Australia, Bosnia and Herzegovina, England and Ireland.

E-mail: dawsona@unimelb.edu.au

Simone Dennis is Head of School, School of Archaeology and Anthropology, at the Australian National University. Her research interests coalesce around phenomenologically informed anthropological theories of embodiment, the senses and power. She has explored these interests in a range of ethnographic contexts, including policing, animal-human interactions in science laboratories, and licit substance use. She is best known for her work on tobacco use and her critical assessments of anthropology's operations in the public arena.

E-mail: simone.dennis@anu.edu.au.

\section{References}

Anderson, B. (1991), Imagined Communities: Reflections on the Origins and Spread of Nationalism (London: Verso).

Barth, F. (1969), Ethnic Groups and Boundaries: The Social Organisation of Culture Difference (Long Grove, IL: Waveland Press).

Bauman, Z. (2003), Liquid Love: On the Frailty of Human Bonds (London: Polity).

Berlant, L. (1998), 'Intimacy: A Special Issue', Critical Inquiry 24, no. 2: 281-288, https://www.jstor.org/ stable/1344169.

Berlant, L. (2008), The Female Complaint: The Unfinished Business of Sentimentality in American Culture (Durham, NC: Duke University Press).

Boffey, D. (2020), 'Dutch Official Advice to Single People: Find a Sex Buddy for Lockdown', The Guardian, 15 May, https://www.theguardian.com/world/2020/ may/15/dutch-official-advice-to-single-people-finda-sex-buddy-for-lockdown-coronavirus. 
Conran, M. (2011), ‘They Really Love Me! Intimacy in Volunteer Tourism', Annals of Tourism Research 38, no. 4: 1454-1473, doi:10.1016/j.annals.2011.03 .014 .

Dawson, A. (Forthcoming), 'Time in the Car: Driving and Crashing in the Modern/Medieval Lockdown City', in Tempo e Sociedade em Suspenso [Time and society in suspension], (eds.) E. Araújo, R. Costa and C. Sales (Lisbon: CIES).

Giddens, A. (1992), The Transformation of Intimacy: Sexuality, Love and Eroticism in Modern Societies (Cambridge: Polity Press).

Gramsci, A. (1997), Selections from the Prison Notebooks (New York: International Publishers).

Harvey, D. (1989), The Condition of Postmodernity: An Enquiry into the Origins of Cultural Change (Cambridge: Blackwell).

Herzfeld, M. (2005), Cultural Intimacy: Social Poetics and the Real Life of States, Societies, and Institutions (London: Taylor and Francis).

Hirsch, J. S., and H. Wardlow (eds.) (2006), Modern Loves: The Anthropology of Romantic Courtship and Companionate Marriage (Ann Arbor: University of Michigan Press).

Illouz, E. (2007). Cold Intimacies: The Making of Emotional Capitalism (Cambridge: Polity Press).

Illouz, E. (2012). Why Love Hurts: A Sociological Explanation (Cambridge: Polity Press).

Jamieson, L. (2011), 'Intimacy as a Concept: Explaining Social Change in the Context of Globalization or Another Form of Ethnocentrism?' Sociological Research Online 16, no. 4, http://www.socresonline .org.uk/16/4/15.html.

Jamieson, L., and R. Simpson (2013), Living Alone: Globalization, Identity and Belonging (Basingstoke, UK: Palgrave Macmillan).
Legg, S. (2010), 'An Intimate and Imperial Feminism: Meliscent Shephard and the Regulation of Prostitution in Colonial India', Environment and Planning D: Society and Space 28, no. 1: 68-94, doi:10.1068/d10507.

Pain, R. (2015), 'Intimate War', Political Geography 44: 64-73, doi:10.1016/j.polgeo.2014.09.011.

Povinelli, E. (2006), The Empire of Love: Toward a Theory of Intimacy, Genealogy, and Carnality (Durham, NC: Duke University Press).

Rapport, N. J., and A. Dawson (1998), 'Home and Movement: A Polemic', in Migrants of Identity: Perceptions of Home in a World of Movement, (eds.) N. J. Rapport and A. Dawson (New York: Berg), 19-38.

Register, L. M., and T. B. Henley (1992), 'The Phenomenology of Intimacy', Journal of Social and Personal Relationships 9, no. 4: 467-481, doi:10.1177/0265407 592094001.

Soysal, L. (2010), 'Intimate Engagements of the Public Kind', Anthropological Quarterly 83, no. 2: 373-399, doi:10.1353/anq.0.0129.

Stoler, A. L. (1989), 'Making Empire Respectable: The Politics of Race and Sexual Morality in 20th Century Colonial Cultures', American Ethnologist 16, no. 4: 634-660, doi:10.1525/ae.1989.16.4.02a00030.

Stoler, A. L. (2006), 'Intimidations of Empire: Predicaments of the Tactile and Unseen', in Haunted by Empire: Geographies of Intimacy in North American History, (ed.) A. L. Stoler (Durham, NC: Duke University Press), 1-22.

Thompson, E. P. (1967), 'Time, Work-Discipline, and Industrial Capitalism', Past and Present 38, no. 1: 56-97, doi:10.1093/past/38.1.56.

Wilson, A. (2012). 'Intimacy: A Useful Category of Transnational Analysis', in The Global and the Intimate, (ed.) G. Pratt and V. Rosner (New York: Columbia University Press), 31-56. 